\title{
Farming and malignant lymphoma in Hancock County, Ohio
}

\author{
R DUBROW,${ }^{1}$ J O PAULSON,${ }^{2}$ R W I N D I A N ${ }^{2}$ \\ From the Division of Surveillance, Hazard Evaluations, and Field Studies, ${ }^{1}$ National Institute for Occupational \\ Safety and Health, Cincinnati, Ohio 45226, and the Chronic Disease and Special Studies Unit, ${ }^{2}$ Ohio \\ Department of Health, Columbus, Ohio 43216, USA
}

ABSTRACT Raised death rates have been reported for non-Hodgkin's lymphoma (NHL) and Hodgkin's disease (HD) among white male residents of Hancock County, Ohio, United States, for 1960-79. As a surveillance activity, to assess the possibility of workplace exposures contributing to these raised rates, a case-control study was conducted using death certificate records of white male Hancock County residents for 1958-83. There were 61 cases of NHL, 15 cases of HD, and 304 control subjects (chosen as a stratified random sample) in the study. Cases and controls were compared with respect to their usual occupation and industry statements on the death certificates, adjusting for age at death and year of death. Summary odds ratios (OR) and test-based $95 \%$ confidence intervals (CI) were calculated. NHL was associated with the occupation of farmer $(\mathrm{OR}=1.6 ; \mathrm{CI}=0.8,3.4$; observed number of exposed cases $(\mathrm{Obs})=15)$. The association was restricted to $1958-73(\mathrm{OR}=2 \cdot 1 ; \mathrm{CI}=0 \cdot 9,4 \cdot 8 ; \mathrm{Obs}=13)$. The three cases of HD among farmers occurred in a cluster in the 15-64 age range during 1958-63 (OR = 21.2). The results for occupations and industries other than farming were based on small numbers and were unremarkable. This small study adds to the growing body of reports linking farming and malignant lymphoma, particularly NHL.

The death rate for non-Hodgkin's lymphoma (NHL) among white male residents of Hancock County, Ohio, United States, showed a statistically significant rise during 1960-791 (table 1). Among the 377 US counties with 20 or more deaths from NHL in white men during 1960-9, Hancock County ranked seventh in death rate. During 1970-9, Hancock County ranked sixth among 469 such counties.

In addition, mortality from Hodkin's disease (HD) among white male residents of Hancock County showed a smaller, non-significant rise during $1960-79^{1}$ (table 1).

The malignant lymphoma mortality experience of white women in Hancock County during 1960-79 was unremarkable. The non-white population of Hancock County is small and there were no deaths from malignant lymphoma among non-whites during this period.

The restriction of excess mortality from NHL and HD to men suggests that these excesses may have been due to a workplace exposure(s) particular to men. As a surveillance activity, to test this possibility

Accepted 12 January 1987 in a preliminary and relatively quick and inexpensive way, researchers from the National Institute for Occupational Safety and Health (NIOSH) and the Ohio Department of Health have conducted a casecontrol study, based on death certificates, of NHL and HD among white men in Hancock County.

\section{Methods}

Cases and controls were selected from a computer tape of all Ohio death certificate records for 1958-83.

Table 1 Average annual age adjusted mortality rates for malignant lymphoma in white men*

\begin{tabular}{|c|c|c|c|c|}
\hline \multirow[b]{3}{*}{ Area } & \multicolumn{4}{|c|}{ Mortality rate (per 100000$) \dagger$} \\
\hline & \multicolumn{2}{|c|}{$\begin{array}{l}\text { Non-Hodgkin's } \\
\text { lymphoma }\end{array}$} & \multicolumn{2}{|c|}{ Hodgkin's disease } \\
\hline & $1960-9$ & $1970-9$ & $1960-9$ & $1970-9$ \\
\hline $\begin{array}{l}\text { Hancock County } \\
\text { Ohio } \\
\text { United States }\end{array}$ & $\begin{array}{l}9 \cdot 9(25)_{+}^{+} \\
6.0 \\
5 \cdot 6\end{array}$ & $\begin{array}{l}10 \cdot 4(28)_{+}^{+} \\
6 \cdot 2 \\
6 \cdot 0\end{array}$ & $\begin{array}{l}3 \cdot 0(7) \\
2 \cdot 5 \\
2 \cdot 3\end{array}$ & $\begin{array}{l}2.4(7) \\
1.8 \\
1.6\end{array}$ \\
\hline
\end{tabular}


This computer file included information on sex, race, county of residence, age at death, year of death, and underlying cause of death. From this file, a subfile was created of death certificate records for all white male residents of Hancock County, aged 15 or more, who died during 1958-83.

Cases were defined as decedents for whom NHL or HD was coded as the underlying cause of death. Coding was done according to the International Classification of Diseases, seventh revision for 1958-67; eighth revision for 1968-78; and ninth revision for 1979-83. The codes for NHL were 200 , 202, and 205 in the seventh revision; 200 and 202 in the eighth revision; and 200 and 202 (except 202.2-202.6) in the ninth revision. The code for HD was 201 in all three revisions.

Four controls per case were chosen as a stratified random sample. Stratification was done by age at death $(15-19,20-24, \ldots 85-89, \geqslant 90)$ and year of death $(1958-63,1964-8,1969-73,1974-8$, and 1979-83). Those whose underlying or secondary cause of death was a neoplasm of the lymphatic and haematopoietic tissue were excluded from the control series.

The few Hancock County residents who died outside Ohio were excluded from both the case and control series because death certificates, which were used to obtain occupation and industry information (see below), were not readily available. Two white male Hancock County residents, whose underlying cause of death was NHL, died outside the state during 1958-83.

Copies were obtained of the death certificates of the cases and controls. The death certificate contains entries for usual occupation ("kind of work done during most of working life, even if retired") and usual industry ("kind of business or industry"). These

Table 2 Number of deaths, summary odds ratios, and 95\% confidence intervals for non-Hodgkin's lymphoma in farmers, by selected variables

\begin{tabular}{|c|c|c|c|}
\hline Variable & $\begin{array}{l}\text { No of } \\
\text { cases }\end{array}$ & $\begin{array}{l}\text { No of } \\
\text { controls }\end{array}$ & Odds ratio $(\mathrm{CI})$ \\
\hline $\begin{array}{l}\text { All farmers } \\
\text { Non-farmers }\end{array}$ & $\begin{array}{l}15 \\
46\end{array}$ & $\begin{array}{r}48 \\
256\end{array}$ & $1 \cdot 6(0 \cdot 8,3 \cdot 4)$ \\
\hline $\begin{array}{l}\text { Year of death: } \\
\text { 1958-73 Farmers } \\
\text { Non-farmers }\end{array}$ & $\begin{array}{l}13 \\
28\end{array}$ & $\begin{array}{r}35 \\
169\end{array}$ & $2 \cdot 1(0 \cdot 9,4 \cdot 8)$ \\
\hline $\begin{array}{l}\text { 1974-83 Farmers } \\
\text { Non-farmers }\end{array}$ & $\begin{array}{r}2 \\
18\end{array}$ & $\begin{array}{l}13 \\
87\end{array}$ & $0.6(0 \cdot 1,4 \cdot 2)$ \\
\hline $\begin{aligned} & \text { 1960-79* } \text { Farmers } \\
& \text { Non-farmers }\end{aligned}$ & $\begin{array}{l}14 \\
36\end{array}$ & $\begin{array}{r}42 \\
219\end{array}$ & $2 \cdot 0(0 \cdot 8,4 \cdot 6)$ \\
\hline $\begin{array}{l}\text { Age at death: } \\
\text { 15-64 Farmers } \\
\text { Non-farmers }\end{array}$ & $\begin{array}{r}4 \\
21\end{array}$ & $\begin{array}{r}13 \\
131\end{array}$ & $1.9(0.4,8.7)$ \\
\hline $\begin{array}{ll}\geqslant 65 & \text { Farmers } \\
& \text { Non-farmers }\end{array}$ & $\begin{array}{l}11 \\
25\end{array}$ & $\begin{array}{r}35 \\
125\end{array}$ & $1 \cdot 5(0 \cdot 7,3 \cdot 6)$ \\
\hline
\end{tabular}

*Year of death stratification: 1960-4, 1965-9, 1970-4, and 1975-9. entries were coded according to the 1980 US Bureau of the Census occupational and industrial classification system. $^{2}$ When more than one occupation or industry were mentioned on the death certificate, all were coded.

The case and control series were compared with respect to usual occupation and industry, adjusting for age at death and year of death, using the strata mentioned above. A decedent was classified into a given occupation or industry if that occupation or industry was mentioned on the death certificate, even if more than one occupation or industry were listed. Summary odds ratio (OR) estimators and chi-square significance tests were calculated using the procedures developed by Mantel and Haenszel. ${ }^{3}$ Test based $95 \%$ confidence intervals $(\mathrm{CI})$ were calculated by the procedure of Miettinen. ${ }^{4}$

\section{Results}

There were 61 cases of NHL, 15 cases of HD, and 304 control subjects in the study. Eight per cent of the subjects could not be assigned a usual industry and $5 \%$ could not be assigned a usual occupation due to insufficient information on the death certificates. Only $1 \%$ of the subjects could not be assigned either a usual industry or a usual occupation.

Farmers constituted the largest single occupation and agriculture the largest industry among the study subjects. Twenty five per cent of the NHL cases, $20 \%$ of the HD cases, and $16 \%$ of the control subjects were farmers. In addition to the farmers the subjects in the agriculture industry included an employee of a nursery, a labourer in a duck hatchery, and a truck driver. Farmers were chosen for further analysis, as opposed to the agriculture industry, for the sake of homogeneity.

The relation between NHL and farmers is presented in table 2 . The overall summary $O R$ was $\mathbf{1 . 6}$ $(\mathrm{CI}=0.8,3.4$; observed number of exposed cases $(\mathrm{Obs})=15)$. The OR was only raised during 1958-73 $(\mathrm{OR}=2 \cdot 1 ; \mathrm{CI}=0 \cdot 9,4 \cdot 8 ; \mathrm{Obs}=13)$ and did not vary appreciably by age at death.

The OR was also calculated for 1960-79 $(\mathrm{OR}=2 \cdot 0, \mathrm{CI}=0 \cdot 8,4 \cdot 6)$ (table 2$)$ in order to evaluate directly the contribution of the excess NHL deaths among farmers to the raised rate of NHL in Hancock County during this period (table 1).

The overall summary OR for HD among farmers was $2 \cdot 7(\mathrm{Obs}=3)$. The three cases occurred in a cluster during 1960-2. The ages of the cases were 21, 44, and 45. The OR in the year of death stratum 1958-63 for farmers age 15-64 was 21·2. The Mantel-Haenszel significance test was inappropriate for results with such small numbers.

The results for occupations and industries other 
than farmers and agriculture were based on small numbers and were unremarkable.

\section{Discussion}

Raised ORs for NHL and HD were observed among farmers in Hancock County, Ohio. Although the NHL result was not statistically significant at the $95 \%$ confidence level due to the small size of the study, and the HD result was based on only three deaths (a number too small to permit statistical testing), these results are noteworthy because increased risks have been reported previously for both $\mathrm{NHL}^{5-11}$ and $\mathrm{HD}^{59}$ in farmers. The disappearance of the association between NHL and farming in Hancock County in more recent years, however, is consistent with only one previous study. ${ }^{11}$ If this association is truly due to occupational exposures this discrepancy could be due to differences in farming practices among geographical regions and calendar periods.

Occupational exposures that are possible aetiological agents include herbicides, insecticides, other pesticides, fertilisers, and zoonotic viruses. In a Swedish case-control study an association was observed between exposure to phenoxy acid herbicides and both HD and NHL. ${ }^{12}$ NHL of the skin was associated with phenoxy acid herbicide use in a NHL case series. ${ }^{13} \mathrm{~A}$ recent population based case-control study in Kansas found the use of farm herbicides to be associated with NHL but not HD ${ }^{14}$ Only a weak, non-significant association between NHL and potential exposure to phenoxy acid herbicides, however, was observed in a case-control study in New Zealand. ${ }^{15}$

In an Iowa death certificate based case-control study NHL among farmers was associated with residence in counties where herbicide use was high. ${ }^{7}$ In a Wisconsin case-control study based on death certificates risks of NHL among farmers were greater in the highest herbicide, fertiliser, and insecticide using counties than in other counties in the state. ${ }^{6}$

A raised risk for malignant lymphoma was found among workers engaged in producing arsenic containing insecticides. ${ }^{16}$ Two cases of NHL were reported to have occurred six years after poisoning with the agricultural nematocide, 1,3-dichloropropene. ${ }^{17} \mathrm{HD}$ was associated with exposure to fertilisers in a case-control study in Yorkshire, England. ${ }^{18}$

Hancock County has been one of the more productive agricultural counties in Ohio, the major crops being corn, wheat, and soybeans. Herbicide use has been heavy in Hancock County compared with Ohio as a whole throughout the study period. ${ }^{19}$ Review of Census of Agriculture data did not show changes in agricultural practices that might account for the dis- appearance of the associations between NHL and $\mathrm{HD}$ and farming in Hancock County in more recent years. ${ }^{19}$

Other lymphatic and haematopoietic neoplasmsleukaemia and multiple myeloma - have also been observed to be in excess among farmers. ${ }^{20}$ This raises the possibility of common aetiological factors for the various lymphatic and haematopoietic neoplasms. The Swedish case-control study, which found both HD and NHL to be similarly associated with exposure to phenoxy acids, chlorophenols, and organic solvents, lends credence to this possibility. ${ }^{12}$ Other reports have linked organic solvent exposure with $\mathrm{HD}^{21}$ and NHL. ${ }^{1822}$ In the present study mortality from both NHL and HD was raised in the earlier years.

The number of excess deaths from NHL among farmers observed in this study was insufficient to explain the high rate of this disease seen in Hancock County during 1960-79 (table 1). Using the US rate as the standard, during this period there were about 23 excess deaths from NHL in Hancock County. Fourteen of those who died from NHL during 1960-79 had a usual occupation of farmer. The odds ratio for NHL among farmers during this period was 2.0 (table 2), indicating that only seven of the 23 excess deaths from NHL were attributable to farming.

The only occupational information available in this study, however, was the usual occupation, so possibly there were other deaths from NHL among subjects who, in addition to their usual occupation, had worked as farmers at some time in their lives. Many farmers in Hancock County have engaged in off farm employment, ${ }^{19}$ which may be listed as the usual occupation/industry on the death certificate instead of farming.

Thus in interpreting the results of this study the limitations of death certificate data should be taken into account. These include inaccuracies in cause of death and occupation and industry information and the crudeness of the occupation and industry information (usual occupation and industry).

Farmers have been reported to have a low overall death rate. ${ }^{23-26}$ If farmers in Hancock County had a lower overall death rate than the general population in Hancock County during 1958-83 this would have led to an underrepresentation of farmers in the control group, biasing the results toward artifactually high odds ratios. This possibility cannot be ruled out. It would be unlikely, however, to account for the entire excess of NHL and it could not explain the HD cluster.

Death certificate based case-control studies may be used as a relatively quick and inexpensive surveillance tool. The present small study adds to the growing 
body of reports linking farming and malignant lymphoma, particularly NHL. Further work is needed to clarify this relation.

Requests for reprints to: Dr Robert Dubrow, Department of Epidemiology and Public Health, Yale University School of Medicine, 60 College Street, PO Box 3333, New Haven, CT 06510, USA.

\section{References}

1 Riggan WB, Van Bruggen J, Acquavella JF, Beaubier J, Mason TJ. US cancer mortality rates and trends, 1950-1979. Vol III Research Triangle Park, North Carolina: US Environmental Protection Agency and National Cancer Institute, 1983.

2 US Bureau of the Census. 1980 census of population, alphabetical index of industries and occupations. Washington, DC: US Government Printing Office, 1982.

3 Mantel N, Haenszel W. Statistical aspects of the analysis of data from retrospective studies of disease. $J$ Natl Cancer Inst 1959;22:719-48.

4 Miettinen O. Estimability and estimation in case-referent studies. Am J Epidemiol 1976;103:226-35.

5 Burmeister LF. Cancer mortality in Iowa farmers, 1971-78. $J$ Natl Cancer Inst 1981;66:461-4.

6 Cantor KP. Farming and mortality from non-Hodgkin's lymphoma: a case-control study. Int J Cancer 1982;29:239-47.

7 Burmeister LF, Everett GD, Van Lier SF, Isacson P. Selected cancer mortality and farm practices in Iowa. Am J Epidemiol 1983;118:72-7.

8 Buesching DP, Wollstadt L. Cancer mortality among farmers. $J$ Natl Cancer Inst 1984;72:503.

9 Giles GG, Lickiss JN, Baikie MJ, Lowenthal RM, Panton J. Myeloproliferative and lymphoproliferative disorders in Tasmania, 1972-80: occupational and familial aspects. $J$ Natl Cancer Inst 1984;72:1233-40.

10 Pearce NE, Smith AH, Fisher DO. Malignant lymphoma and multiple myeloma linked with agricultural occupations in a New Zealand cancer registry-based study. Am J Epidemiol 1985;121:225-37.

11 Schumacher MC. Farming occupations and mortality from nonHodgkin's lymphoma in Utah. J Occup Med 1985;27:580-4.
12 Hardell L, Eriksson M, Lenner P, Lundgren E. Malignant lymphoma and exposure to chemicals, especially organic solvents, chlorophenols and phenoxy acids: a case-control study. Br J Cancer 1981;43:169-76.

13 Olsson H, Brandt L. Non-Hodgkin's lymphoma of the skin and occupational exposure to herbicides. Lancet 1981;ii:579.

14 Hoar SK, Blair A, Holmes FF, et al. Agricultural herbicide use and risk of lymphoma and soft-tissue sarcoma. JAMA 1986;256:1141-7.

15 Pearce NE, Smith AH, Howard JK, Sheppard RA, Giles HJ, Teague CA. Non-Hodgkin's lymphoma and exposure to phenoxyherbicides, chlorophenols, fencing work, and meat works employment: a case-control study. $\mathrm{Br} J$ Ind Med 1986;43:75-83.

16 Ott MG, Holder BB, Gordon HL. Respiratory cancer and occupational exposure to arsenicals. Arch Environ Health 1974;29:250-5.

17 Markovitz A, Crosby WH. Chemical carcinogenesis-a soil fumigant, 1,3-dichloropropene, as possible cause of hematologic malignancies. Arch Intern Med 1984;144:1409-11.

18 Bernard SM, Cartwright RA, Bird CC, Richards IDG, Lauder I, Roberts BE. Aetiologic factors in lymphoid malignancies: a case-control epidemiological study. Leuk Res 1984;8:681-9.

19 US Bureau of the Census. Census of agriculture, statistics for the state and counties, Ohio, 1945, 1954, 1964, 1974, 1978. Washington, DC: US Government Printing Office, 1946, 1956, 1967, 1977, 1980.

20 Blair A, Malker H, Cantor KP, Burmeister L, Wiklund K. Cancer among farmers-a review. Scand J Work Environ Health 1985:11:397-407.

21 Olsson H, Brandt L. Occupational exposure to organic solvents and Hodgkin's disease in men-a case-referent study. Scand $J$ Work Environ Health 1980;6:302-5.

22 Capurro PU, Eldridge JE. Solvent exposure and cancer. Lancet 1978;i:942.

23 Guralnick L. Mortality by occupation and cause of death among men 20 to 64 years of age: United States, 1950. Washington, DC: Public Health Service, 1963. (Vital statistics-special reports 53, No 3.)

24 Registrar General. Occupational mortality-decennial supplement for England and Wales, 1970-1972. London: HMSO, 1978.

25 Pomrehn PR, Wallace RB, Burmeister LF. Ischemic heart disease mortality in lowa farmers - the influence of lifestyle. JAMA 1982;248:1073-6.

26 Walrath J, Rogot E, Murray J, Blair A. Mortality patterns among US veterans by occupation and smoking status. Bethesda, MD: National Institutes of Health, 1985. (NIH publ No 85-2756.) 